\title{
PENGEMBANGAN BAHAN AJAR IPS BERBASIS NILAI BUDAYA USING UNTUK SISWA SEKOLAH DASAR
}

\author{
F. S. Hutama \\ Program Studi Pendidikan Guru Sekolah Dasar, \\ Universitas Jember, Indonesia \\ E-mail: fajarsurya.fkip@unej.ac.id
}

\begin{abstract}
Abstrak
Produk bahan ajar IPS berbasis nilai budaya Using untuk siswa kelas IV SDN 01 Kemiri Kecamatan Singojuruh Kabupaten Banyuwangi dikembangkan berdasarkan KTSP SK 1 KD 1.4. Bahan ajar yang dibuat berupa modul belajar siswa dan modul panduan guru dengan judul "Keanekaragaman suku bangsa dan budaya". Kelayakan produk bahan ajar berbasis nilai budaya Using diukur berdasarkan tingkat validitas, kemenarikan, keefektifan, dan keterterapan produk. Tingkat validitas diperoleh dari hasil uji validasi ahli, persentase validitas dari ahli bahasa untuk modul belajar siswa adalah $97,92 \%$ (sangat valid) dan modul panduan guru adalah $96,43 \%$ (sangat valid), persentase dari ahli desain untuk modul belajar siswa adalah $88,89 \%$ (sangat valid) dan modul panduan guru adalah $94,44 \%$ (sangat valid), dan persentase dari ahli isi untuk modul belajar siswa adalah 97,32\% (sangat valid) dan modul panduan guru adalah $97,73 \%$ (sangat valid). Tingkat kemenarikan diukur dari uji coba perorangan yang mendapatkan skor $78,33 \%$ (cukup menarik) dan uji coba kelompok kecil memperoleh persentase skor $85,71 \%$ (menarik). Tingkat keefektifan bahan ajar diukur dari aktivitas belajar siswa yang mendapatkan persentase skor $91,56 \%$ (sangat aktif) dan hasil belajar siswa mendapatkan persentase skor $80,49 \%$ (tuntas). Tingkat keterterapan produk bahan ajar diukur berdasarkan angket tanggapan guru yang mendapatkan persentase skor $93,18 \%$ (sangat baik) untuk modul belajar siswa dan $89,29 \%$ (sangat baik) untuk modul belajar guru, sedangkan angket tanggapan siswa mendapatkan persentase skor 76,80\% (cukup baik).
\end{abstract}

Kata kunci: bahan ajar IPS dan nilai budaya Using.

\begin{abstract}
Product instructional learning of IPS Using cultural values for fourth grade students of SDN 01 Kemiri Singojuruh Banyuwangi developed by KTSP SK 1 KD 1.4. Instructional learning is made in the form of student learning modules, and modules guide teachers with the title "ethnic and cultural diversity". Feasibility products based teaching materials Using cultural values measured by the level of validity, the attractiveness, effectiveness, and applied products. The validity of the results obtained from the expert validation test, the percentage of the validity of expert of languages for student learning module is $97.92 \%$ (very valid) and a teacher's guide module is $96.43 \%$ (very valid), the percentage of design experts to student learning module is $88.89 \%$ (very valid) and a teacher's guide module is $94.44 \%$ (very valid), and the percentage of the content expert for student learning module is $97.32 \%$ (very valid) and a teacher's guide module is $97.73 \%$ (very valid). The attractiveness of the measured level of individual testing that get a score of $78.33 \%$ (interestingly enough) and a small group trial obtain a percentage score of $85.71 \%$ (interest). The effectiveness of teaching materials is measured from the learning activities of students who get a percentage score of $91.56 \%$ (very active) and student learning outcomes receive a percentage score of $80.49 \%$ (complete). Applied level product instructional materials measured by the questionnaire responses of teachers who get a percentage score of $93.18 \%$ (excellent) for student learning modules and $89.29 \%$ (excellent) for teacher learning modules, while the questionnaire responses of students get a percentage score of $76.80 \%$ (pretty good).
\end{abstract}

Keywords: instructional learning of IPS and cultural values Using 


\section{PENDAHULUAN}

IPS merupakan salah satu mata pelajaran wajib yang diberikan pada jenjang Sekolah Dasar. Sukadi (2005) adanya mata pelajaran IPS di SD (Sekolah Dasar) diharapkan dapat membentuk kemampuan siswa dalam memahami kondisi lingkungannya, mulai dari bergaul, menyikapi permasalahan, sampai menyelesaikannya. Karakteristik utama pembelajaran IPS adalah adanya pembentukan nation and character building. Tujuan utama pembelajaran IPS di SD adalah menanamkan kesadaran akan posisi individu, baik dalam kapasitasnya sebagai pribadi maupun sebagai anggota komunitas. Pembelajaran ini bersifat strategis (Farisi, 2001). Artinya, keberhasilan pembelajaran IPS di SD akan mengantarkan siswa pada situasi sadar budaya. Mereka diharapkan memiliki kesadaran bahwa dirinya tidak bisa hidup terpisah dari jaringan kehidupan sosial-budaya yang lebih luas. Oleh karena itu, mereka juga harus memiliki kepribadian yang terpuji. Untuk mencapai hal itu, materi pembelajaran sudah seharusnya dikembangkan berdasarkan berbagai potensi yang tersedia di sekitar kehidupan mereka. Dengan kata lain, budaya lokal yang tersedia dan dekat dengan proses berlangsungnya pendidikan merupakan suatu hal yang layak diberdayakan dan dimanfaatkan sebaikbaiknya.

Kondisi pembelajaran IPS dewasa ini khususnya pada jenjang SD, menunjukkan indikasi adanya pengabaian terhadap kebudayaan lokal yang berfungsi untuk membangun karakter siswa. Hal itu tercermin dari pengorganisasian materi yang disusun oleh guru IPS di SD. Materi cenderung hanya fokus pada wawasan global yang menyebabkan sikap humanis dan nasionalisme siswa memudar. Oleh sebab itu, harus dicarikan solusi yang tepat dan bersifat segera, agar substansi dan esensi dari pembelajaran IPS di sekolah dasar dapat terealisasi dengan benar dan sesuai dengan harapan, yaitu lahirnya manusia-manusia Indonesia yang berkualitas dan siap berkompetisi di era global dalam warna nilainilai sosial dan budaya masyarakat Indonesia yang luhur (Hasan, 2009; Lasmawan, 2008). Pembelajaran IPS sebagai proses sosialisasi dan pembudayaan manusia, memanusiakan manusia (Stahl, 2002), harus mampu mengkondisikan dan memediasi pengembangan potensi peserta didik secara optimal, sehingga mereka benar-benar merasakan dampak dan manfaat dari belajarnya (meaningful learning). Untuk itu, pembelajaran yang dilakukan di sekolah hendaknya tidak terlepas dari referensi sosial dan budaya dari masyarakat itu sendiri. Referensi sosial budaya jika digunakan dalam pengembangan pendidikan, diduga akan menghindarkan para pemikir, pengambil kebijakan, dan para pelaksana serta pelaku pendidikan dari kondisi "keterbelengguan" dan "determinisme" pemikiran pendidikan (Suwarma, 2001; Lasmawan, 2008). Kemajemukan, baik vertikal maupun horizontal merupakan penomena sosial budaya dan latar pendidikan bagi manusia Indonesia, oleh sebab itu, pembelajaran IPS harus mampu mengakomodasi nilai-nilai sosial dan budaya masyarakat setempat (local genius) dalam keseluruhan proses dan hasil belajarnya.

Kemampuan dan keterampilan guru dalam mengorganisasikan materi merupakan "kurikulum nyata" yang menjadi "dokumen dasar guru" dalam melaksanakan pembelajaran berdasarkan KTSP. Menurut Arthur (2007) dan Somantri (2004), iklim pembelajaran dan model pengorganisasian materi ajar yang termuat dalam silabus (kurikulum operasional) hendaknya tidak hanya mengandung rekayasa "instrumentalistik", sehingga semakin menjauhkan kodrat dan bakat peserta didik yang terlepas dari referensi sosial budaya kemasyarakatan. Sejalan dengan konsepsi tersebut, berdasarkan pengamatan dan antisipasi pendidikan pada era hightectinformation dan pemberlakuan KTSP saat ini, tampaknya pembelajaran IPS harus dapat memainkan peran dan fungsinya secara tepat dan komprehensif, sehingga mampu menjauhkan peserta didik dari dampak negatif revolusi sosial-budaya gelombang ketiga (Hasan, 2009; Toffler, 1987). Untuk itu, pembelajaran IPS di sekolah dasar, yang secara umum peserta didiknya masih ada dalam usia operasional-kongkrit (Piaget, 1981), memerlukan instrumen-instrumen khusus pembentukan pribadi dan tata nilai yang nantinya menjadi they belief. Untuk mencapai hal itu, pembelajaran IPS SD harus didukung oleh model pengorganisasian 
materi, model pembelajaran, buku ajar, dan perangkat penilaian yang berwawasan sosial dan budaya, sehingga memungkinkan peserta didik mencapai tingkat literasi sosialbudaya yang optimal.

Pengorganisasian materi, model pembelajaran, buku ajar, dan perangkat penilaian sebagai sebuah piranti utama pembelajaran dalam konteks pembelakuan kurikulum 2006, harus dirancang sendiri oleh guru dengan mempertimbangkan beberapa kaidah standar nasional pendidikan, diantaranya adalah standar kompetensi, standar isi, standar kelulusan, dan kompetensi dasar (Puskur, 2006; Depdiknas, 2007). Sementara aspek dan indikator lainnya, diserahkan sepenuhnya kepada guru, karena hanya guru yang tahu bagaimana latar social-budaya dan karakteristik peserta didiknya, termasuk kebutuhan dan tujuan program pendidikan di daerahnya masing-masing.

Jika dalam perancangan dan pelaksanaan pembelajaran IPS di sekolah dasar, guru mengabaikan aspek sosial dan budaya masyarakat setempat, maka dapat diartikan bahwa pembelajaran yang akan dilakukannya telah gagal sejak awal. Jika hal ini dianalogikan, dapat dikatakan bahwa guru telah kalah sebelum bertanding. Hal ini bisa dipahami, karena dalam kurikulum 2006, pembelajaran IPS - SD dengan "tegas" dan "mutlak" dinyatakan bahwa pengembangan materi, model pengorganisasian materi, model pembelajaran, dan perangkat penilaian serta perangkat pengiring pembelajaran lainnya diserahkan sepenuhnya kepada guru, dan dalam pelaksanaannya harus disesuaikan dengan latar sosial dan budaya masyarakat, kebutuhan belajar peserta didik, dan kebutuhan serta tujuan pelaksanaan program pendidikan di daerahnya masing-masing dengan tetap berorientasi pada beberapa ketentuan administrasi yang telah ditetapkan secara nasional.

\section{Pendekatan sosial-budaya} merupakan penghampiran dan pengorganisasian materi yang menghadirkan copy (potret) riil kehidupan masyarakat sehari-hari, baik dimensi sosial maupun budayanya secara komprehensif ke dalam kelas, dalam suasana yang terbuka, actual, dan factual (NCSS, 2007; McConverter,
2006). Melalui penghadiran potret riil dimensi sosial-budaya kedalam kelas, diharapkan peserta didik merasa belajar dalam realitas kehidupannya sehari-hari, sehingga tidak mengalami shoch-learning situation (Waterworth, 2007). Model pengorganisasian materi, model pembelajaran, dan perangkat penilaian berwawasan sosial-budaya merupakan sebuah "pengembangan kurikulum operasional" yang mengakomodasi nilai-nilai sosial dan budaya masyarakat lokal, regional, dan nasional secara komprehensif dalam keseluruhan aspeknya (Hasan, 2007; Dantes, 2008), sehingga dalam penerapannya di dalam kelas akan mengkondisikan peserta didik untuk mencapai apa yang dikenal dengan literasi sosial-budaya sesuai dengan esensi dari pembelajaran IPS pada jenjang sekolah dasar.

Berdasarkan logika dan preposisi di atas, bisa disadari betapa esensial dan urgennya pengembangan model pengorganisasian materi, model pembelajaran, buku ajar, dan perangkat penilaian IPS yang berwawasan sosialbudaya dalam rangka pemberlakuan KTSP pada jenjang sekolah dasar. Akomodasi nilainilai sosial dan budaya dalam konteks pembelajaran IPS, bisa dilakukan dengan memasukkan aspek sosial dan budaya masyarakat, mulai dari saat perancangan program pembelajaran, pelaksanaan pembelajaran, dan pelaksanaan penilaian terhadap capaian hasil belajar siswa (Hasan, 2009; McConverter, 2007).

Hal ini penting dilakukan, dengan harapan bahwa melalui nilai-nilai budaya yang dimiliki masyarakat, lewat proses pembelajaran akan menjadi nilai-nilai yang dihayati dan diinternalisasi oleh peserta didik sebagai warga masyarakat secara individual. Preposisi di atas, sejalan dengan penekanan yang diberikan oleh Somantri (2004) dan Lasmawan (2007) bahwa pembelajaran IPS di sekolah dasar harus mampu menjembatani dan memfungsionalkan segala aspek sosial dan budaya masyarakat dalam proses pembelajaran yang kondusif, sehingga peserta didik mempunyai ketahanan dan literasi terhadap masalahmasalah sosial dan budaya masyarakatnya.

Menurut Lestari (2012) bahan ajar adalah seperangkat sarana atau alat 
pembelajaran yang berisikan materi dan metode pembelajaran, serta evaluasi yang didesain secara sistematis dalam rangka mencapai tujuan pembelajaran yang diharapkan. Bahan ajar mempunyai peranan yang sangat penting dalam proses pembelajaran yaitu sebagai acuan bagi siswa dan guru untuk meningkatkan efektifitas pembelajaran. Bagi siswa, bahan ajar menjadi bahan acuan yang diserap isinya, sehingga dapat menjadi sumber pengetahuan. Bagi guru, bahan ajar menjadi salah satu acuan dalam penyampaian ilmu/materi kepada siswa. Bahan ajar yang dirancang dan dikembangkan berdasarkan prinsip-prinsip instruksional yang baik akan dapat membantu siswa dalam proses belajarnya, membantu guru untuk mengurangi waktu penyajian materi dan memperbanyak waktu pembimbingan guru bagi siswa. (Pannen \& Purwanto, 2001).

Bahan ajar yang dikembangkan adalah bahan ajar yang berupa modul. Menurut Prastowo (2011) modul merupakan bahan ajar yang ditulis dengan tujuan agar siswa dapat belajar secara mandiri tanpa atau dengan bimbingan guru, oleh karena itu modul harus berisi tentang petunjuk belajar, kompetensi yang akan dicapai, isi materi pelajaran, informasi pendukung, latihan soal, petunjuk kerja, evaluasi dan balikan terhadap hasil evaluasi. Menurut Lestari (2012), pembelajaran menggunakan modul membuat siswa dapat belajar mandiri tanpa harus dibantu oleh guru. Siswa yang memiliki kecepatan belajar kurang dapat berkali-kali mempelajari setiap kegiatan belajar tanpa terbatas oleh waktu, sedangkan siswa yang memiliki kecepatan belajar lebih, akan cepat mempelajari satu kompetensi dasar (KD). Berdasarkan definisi di atas, maka dapat disimpulkan bahwa modul merupakan bahan ajar yang disusun secara sistematis dan teoretis. Modul memiliki ciri untuk memandirikan siswa, dengan dan tanpa guru siswa dapat belajar menggunakan modul. Modul juga sangat mewadahi kecepatan belajar siswa yang berbeda-beda.

Modul yang dikembangkan adalah modul berbasis nilai budaya using. Kebudayaan Using merupakan salah satu budaya yang ada di Indonesia, tepatnya di Kabupaten Banyuwangi, sebuah Kabupaten yang terletak di ujung timur Provinsi Jawa
Timur. Dari 21 Kecamatan di Kabupaten Banyuwangi, tercatat tinggal 9 Kecamatan saja yang saat ini masih menjadi kantong kebudayaan Using. Kecamatan-kecamatan tersebut adalah Banyuwangi, Giri, Glagah, Kabat, Rogojampi, Songgon, Singojuruh, Cluring, dan Genteng (Sutarto, 2006:1).

Orang Using terkenal sangat kaya akan produk-produk keseniannya, diantaranya ada seni tari, alat musik, dan lagu-lagu tradisional. Seni tari yang merupakan budaya masyarakat Using diantaranya: Gandrung, Seblang, Janger, dan lain sebagainya. Selain seni tari, juga terdapat alat musik yang merupakan budaya masyarakat Using diantaranya: Angklung Banyuwangi meliputi angklung Caruk, angklung Tetak, angklung Paglak, dan angklung Blambangan.

Kesenian pada masyarakat Using merupakan produk adat yang mempunyai relasi dengan nilai religi dan pola mata pencaharian di bidang pertanian. Laku hidup masyarakat Using yang masih menjaga adat serta pemahaman mereka terhadap pentingnya kesenian sebagai ungkapan syukur dan kegembiraan masyarakat petani telah menjadikan kesenian Using tetap terjaga. Hal tersebut menunjukkan kondisi yang positif, namun demikian apabila kesenian tersebut tidak terinternalisasi kepada generasi penerus, maka bukan tidak mungkin keseninan yang menjadi kekayaan budaya bangsa ini akan semakin memudar dan hilang ditelan perkembangan zaman, terlebih dengan adanya globalisasi yang secara nyata telah merongrong nasionalisme suatu bangsa.

\section{METODE}

Model penelitian pengembangan yang dilakukan pada pengembangan bahan ajar berbasis nilai budaya Using ini menggunakan model Dick \& Carey. Penggunaan moc 820 dimodifikasi hanya dilakukan sampai paud tahap ke sembilan. Hal ini dilakukan karena dalam penelitian ini hanya akan diperoleh hasil berupa prototype produk dan sesuai dengan tujuan pengembangan yaitu menghasilkan bahan ajar berbasis nilai budaya Using yang valid, menarik, efektif dan dapat diterapkan dalam proses pembelajaran.

Dua jenis data yang dikumpulkan dalam pengembangan bahan ajar ini yaitu: data 
yang diperlukan untuk merevisi produk bahan ajar yang bersumber dari ahli materi/isi, ahli bahasa, ahli media, serta guru dan siswa melalui uji coba lapangan. Data yang dihimpun mengenai kualitas bahan ajar, kemenarikan serta isi materi dalam bahan ajar dan data yang berkaitan dengan proses dan hasil belajar melalui uji lapangan. Data tersebut diperoleh dari nilai hasil tes siswa, sikap siswa berdasarkan angket yang diisi oleh mereka, dan lembar observasi perilaku siswa.

Sumber data penelitian ini mencakup sumber data dokumenter, siswa, dan guru. Sumber data dokumenter berupa KTSP untuk SD yang memuat SK dan KD serta berbagai pustaka yang relevan. Siswa dan guru yang menjadi sumber data adalah siswa dan guru kelas IV SDN Kemiri 01 Kecamatan Singojuruh Kabupaten Banyuwangi.

Terdapat beberapa teknik yang digunakan dalam pengumpulan data, yaitu teknik dokumenter, teknik kuesioner, teknik observasi, dan teknik tes. Untuk memperoleh sejumlah data yang diharapkan, maka digunakan instrumen pengumpulan data. Aspek-aspek yang dinilai, instrumen yang digunakan, data yang diamati, dan responden yang terlibat tersaji pada Tabel 1.

Tabel 1. Aspek yang Dinilai, Instrumen, Data yang Diamati, dan Responden

\begin{tabular}{|c|c|c|c|c|}
\hline Tujuan & $\begin{array}{c}\text { Aspek yang } \\
\text { Dinilai }\end{array}$ & Instrumen & Data yang Diamati & Responden \\
\hline \multirow{5}{*}{$\begin{array}{l}\text { Kelayakan } \\
\text { produk } \\
\text { bahan ajar } \\
\text { berbasis } \\
\text { nilai } \\
\text { budaya } \\
\text { Using }\end{array}$} & Validitas produk & $\begin{array}{l}\text { Lembar } \\
\text { validasi }\end{array}$ & $\begin{array}{l}\text { Kevalidan modul } \\
\text { belajar siswa dan } \\
\text { modul panduan guru }\end{array}$ & $\begin{array}{l}\text { - Ahli materi/isi } \\
\text { - Ahli desain } \\
\text { - Ahli bahasa }\end{array}$ \\
\hline & Keefektivan & Lembar tes & Hasil belajar siswa & Siswa \\
\hline & produk & $\begin{array}{l}\text { Lembar } \\
\text { observasi }\end{array}$ & Aktivitas belajar siswa & $\begin{array}{l}\text { Observer } \\
\text { (guru) }\end{array}$ \\
\hline & Kemenarikan & Angket & Respon siswa & Siswa \\
\hline & Keterterapan & $\begin{array}{l}\text { Pedoman } \\
\text { wawancara }\end{array}$ & $\begin{array}{l}\text { Respon siswa dan } \\
\text { Respon guru }\end{array}$ & $\begin{array}{l}\text { Guru dan } \\
\text { siswa }\end{array}$ \\
\hline
\end{tabular}

Analisis deskriptif kualitatif digunakan untuk menganalisis data berupa catatan, saran, atau komentar yang terdapat pada lembar validasi, lembar observasi, dan angket. Analisis deskriptif kuantitatif digunakan untuk menganalisis data berupa skor dari hasil lembar validasi, lembar observasi, dan angket. Terdapat dua data dalam analisis data deskriptif kuantitatif.

Pertama, data pada analisis kevalidan merupakan data yang menggambarkan kevalidan modul belajar siswa dan modul panduan guru yang telah dikembangkan. Validitas bahan ajar diperoleh dari ahli bahasa, ahli desain, dan ahli isi/materi. Selanjutnya diberikan penafsiran dan pengambilan keputusan tentang kualitas produk pengembangan menggunakan kriteria validitas Seperti tabel 2.

Bahan ajar dinyatakan valid untuk digunakan jika mendapat kriteria "cukup valid" dan/atau "sangat valid". Data kemenarikan produk bahan ajar diperoleh dari angket yang diberikan kepada siswa melalui uji perorangan dan uji kelompok kecil dalam menggunakan produk bahan ajar. Penafsiran terhadap hasil analisis data responden dilakukan berdasarkan Tabel 3.

Tabel 2. Konversi Tingkat Validitas dan Kualifikasi

\begin{tabular}{ccc}
\hline No. & Kriteria & Tingkat Validitas \\
\hline 1. & $75,01 \%-100,00 \%$ & Sangat valid (dapat digunakan tanpa revisi) \\
2. & $50,01 \%-75,00 \%$ & Cukup valid (dapat digunakan dengan revisi kecil) \\
3. & $25,01 \%-50,00 \%$ & Tidak valid (tidak dapat digunakan) \\
4. & $00,00 \%-25,00 \%$ & Sangat tidak valid (terlarang digunakan) \\
\hline & & (Diadaptasi dari Akbar dan Sriwiyana, 2011:207)
\end{tabular}


Tabel 3. Kriteria Kemenarikan Produk Bahan Ajar

\begin{tabular}{cccc}
\hline No & Persentase & Kualifikasi & Keterangan \\
\hline 1 & $80 \%-100 \%$ & Menarik & Dapat digunakan tanpa revisi \\
2 & $60 \%-79 \%$ & Cukup Menarik & $\begin{array}{c}\text { Dapat digunakan dengan revisi } \\
\text { kecil }\end{array}$ \\
3 & $50 \%-59 \%$ & Kurang Menarik & Tidak dapat digunakan \\
4 & $<49 \%$ & Tidak Menarik & Terlarang digunakan \\
\hline
\end{tabular}

(Diadaptasi dari Akbar \& Sriwiyana, 2011:147)

Bahan ajar dinyatakan menarik untuk digunakan jika mendapat kualifikasi "cukup menarik" dan/atau "menarik". Aktivitas siswa diperoleh melalui kegiatan observasi yang dilakukan selama kegiatan pembelajaran pada saat uji coba lapangan. Penentuan tingkat aktivitas siswa dari hasil observasi menggunakan persentase melalui pengelompokan kategori pada Tabel 4.

Tabel 4. Kriteria Keaktifan Siswa

\begin{tabular}{ccc}
\hline No & Persentase & Keterangan \\
\hline 1 & $80 \% \leq \mathrm{Ps} \leq 100 \%$ & Sangat aktif \\
2 & $60 \% \leq \mathrm{Ps} \leq 79 \%$ & Aktif \\
3 & $40 \% \leq \mathrm{Ps} \leq 69 \%$ & Cukup aktif \\
4 & $\mathrm{Ps} \leq 39 \%$ & Tidak aktif \\
\hline
\end{tabular}

Keefektifan produk bahan ajar dilihat dari aktivitas siswa selama pembelajaran pada saat uji coba lapangan minimal memperoleh kriteria "aktif". Analisis hasil belajar diperoleh dari tes yang diberikan kepada siswa dalam Uji Kompetensi yang ada dalam produk bahan ajar berbasis nilai budaya Using. Siswa dinyatakan tuntas jika telah mencapai skor $\geq 70$ dari skor maksimal 100. Hasil belajar akhir siswa secara klasikal dinyatakan tuntas, apabila banyaknya siswa yang tuntas belajar lebih besar atau sama dengan $75 \%$ dari jumlah siswa yang mencapai skor $\geq 70$ dari skor maksimal 100 .
(Diadaptasi dari Siswoyo, 2012)

Kondisi ini menyesuaikan dengan kriteria ketuntasan minimal (KKM) untuk mata pelajaran IPS pada siswa kelas IV SDN 01 Kemiri Kecamatan Singojuruh Kabupaten Banyuwangi. Data keterterapan produk bahan ajar diperoleh dari uji coba lapangan menggunakan angket. Data keterterapan diperoleh dari angket tanggapan guru dan siswa pada saat uji coba lapangan.

Berdasarkan hasil tersebut, kemudian diberikan penafsiran dan pengambilan keputusan tentang kualitas produk menggunakan kriteria keterterapan produk pada Tabel 5.

Tabel 5. Kriteria Tingkat Keterterapan Produk Bahan Ajar

\begin{tabular}{cccc}
\hline No & Persentase & Kualifikasi & Keterangan \\
\hline 1 & $80 \%-100 \%$ & Sangat Baik & Dapat digunakan tanpa revisi \\
2 & $60 \%-79 \%$ & Cukup baik & Dapat digunakan dengan revisi kecil \\
3 & $50 \%-59 \%$ & Kurang baik & Tidak dapat digunakan \\
4 & $<49 \%$ & Tidak baik & Terlarang digunakan \\
\hline
\end{tabular}

(Diadaptasi dari Akbar dan Sriwiyana, 2011:207)

\section{HASIL DAN PEMBAHASAN}

Pengembangan bahan ajar IPS berbasis nilai budaya Using ini dilakukan menggunakan model Dick \& Carey (Modifikasi dari Hobri, 2010:7-8) yang melalui tahapan berikut: Identifikasi tujuan pembelajaran (identify an instructional goal): identifikasi ini dilakukan dengan menganalisis standar kompetensi (SK) dan kompetensi dasar (KD), serta indikator pembelajaran sebagai dasar untuk mengembangkan bahan ajar; Melakukan analisis pembelajaran (conduct an instructional analysis): tujuan analisis 
pembelajaran ini adalah untuk menentukan kompetensi yang harus dikuasai siswa, yang terintegrasi dengan nilai-nilai budaya Using; Tingkah laku masukan dan ciri-ciri siswa (identify entry behavaors and characteristics): tindakan yang dilakukan untuk menganalisis karakteristik siswa kelas IV SDN 01 Kemiri Kecamatan Singojuruh Kabupaten Banyuwangi adalah dengan menganalisis latar belakang kemampuan akademik siswa yang didasarkan pada hasil belajar pada KD sebelumnya. Selain itu analisis karakteristik siswa juga dilakukan melalui observasi yang dilakukan saat proses pembelajaran oleh guru, serta informasi yang diperoleh dari guru; Merumuskan tujuan performasi (write performance objectives): rumusan tujuan pembelajaran dalam pengembangan bahan ajar IPS berbasis nilai budaya Using ini dijabarkan untuk menentukan proses pembelajaran yang akan dilaksanakan; Mengembangkan butir-butir penilaian acuan patokan/ PAP (develop criterion referenced test items): instrumen penilaian dalam bahan ajar IPS berbasis nilai budaya Using disajikan dalam kegiatan pembelajaran dan bagian akhir bahan ajar (modul). Instrumen penilaian disajikan dalam bentuk kegiatan mandiri siswa.

Pada bagian akhir bahan ajar juga disajikan uji kompetensi. Uji Kompetensi pada modul bertujuan untuk mengukur kemampuan siswa pada KD yang diajarkan. Penilaian proses dilakukan melalui pengamatan untuk mengetahui proses yang dilakukan siswa dalam memahami konsep, menginternalisasikan nilai-nilai tertentu serta informasi tentang perilaku belajar siswa. Penilaian aspek sikap yang terinternalisasi nilai budaya Using dilakukan menggunakan lembar observasi dengan kriteria penskoran nilai tertentu; Mengembangkan strategi pembelajaran (develop an instructional strategy): strategi pembelajaran dalam bahan ajar IPS berbasis nilai budaya Using dikembangkan berdasarkan komponenkomponen pembelajaran yaitu: pertama, Prakegiatan ( \pm 5 menit); kedua, Kegiatan awal ( \pm 10 menit); ketiga, Kegiatan inti $( \pm 45$ menit); dan keempat, Kegiatan penutup ( \pm 10 menit); Mengembangkan dan memilih material pembelajaran (develop and select instructional materials): materi pelajaran dalam bahan ajar IPS berbasis nilai budaya Using ini disusun berdasarkan kompetensi yang terdapat dalam KTSP untuk siswa kelas IV dengan SK 1 dan KD 1.4.

Produk pada penelitian ini adalah "Bahan Ajar IPS Berbasis Nilai budaya Using" yang terdiri dari Modul Panduan Guru dan Modul Belajar Siswa; Merancang dan melakukan penilaian formatif (design and conduct the formative evaluation): pada tahap ini, bahan ajar yang sudah dikembangkan berupa draft awal, selanjutnya dilakukan uji validasi, uji coba perorangan, uji coba kelompok kecil dan uji lapangan untuk mendapatkan produk akhir yang layak digunakan dengan kriteria valid, efektif, menarik dan keterterapan. Penilaian formatif dilakukan dengan menyusun terlebih dahulu instrumen penelitiannya. Instrumen tersebut antara lain: lembar validasi, angket tanggapan guru dan siswa, lembar penilaian, dan lembar observasi dan Merevisi pembelajaran (revise instructional): revisi tahap pertama dilakukan setelah dilakukan uji validasi produk melalui catatan berupa komentar dan saran dari ahli bahasa, ahli desain dan ahli materi/isi.

Revisi tahap ke dua dilakukan setelah pelaksanaan uji coba perorangan melaui catatan berupa saran dan komentar dalam angket tanggapan siswa. Revisi tahap ke tiga dilakukan melaui uji coba kelompok kecil yang melibatkan enam orang siswa. Revisi tahap ke empat merupakan langkah revisi terakhir agar produk-produk yang dikembangkan layak digunakan. Pada tahap ini revisi dilakukan berdasarkan uji lapangan. Data kuantitatif dan kualitatif pada instrumen uji lapangan digunakan sebagai rujukan revisi tahap terakhir pada proses pengembangan bahan ajar berbasis nilai budaya Using, yang nantinya menjadi produk akhir pengembangan.

Uji ahli bahasa digunakan untuk mengevaluasi bahasa yang digunakan dalam penulisan bahan ajar. Bahan ajar yang dikembangkan diharapkan memiliki tingkat keterbacaan yang tinggi, sehingga dapat meningkatkan aktivitas dan hasil belajar siswa. Adapun hasil validasi ahli bahasa terhadap bahan ajar berbasis nilai budaya sebagai berikut: perolehan hasil validasi dari ahli bahasa untuk modul belajar siswa mendapatkan persentase skor 
sebesar 97,92\%. Sesuai dengan konversi tingkat validitas dan kualifikasi (tersaji pada tabel 2), hasil validasi dari ahli bahasa ini termasuk dalam kategori "Sangat Valid", sehingga modul belajar siswa ini dapat digunakan tanpa revisi. Adapun hasil validasi ahli bahasa untuk modul panduan guru, perolehan hasil uji validasi ahli bahasa pada modul panduan guru mendapat skor persentase sebesar $96,43 \%$. Sesuai dengan konversi tingkat validitas dan kualifikasi (tersaji pada tabel 2), hasil validasi dari ahli bahasa ini termasuk dalam kategori "Sangat Valid", sehingga modul panduan guru ini dapat digunakan tanpa revisi.

Uji validasi ahli desain bertujuan untuk mengevaluasi desain bahan ajar yang sudah dikembangkan, sehingga bahan ajar ini nantinya memiliki kelebihan tersendiri. Adanya kelebihan dari bahan ajar ini diharapkan dapat meningkatkan aktivitas dan perolehan hasil belajar siswa. Adapun hasil validasi ahli desain terhadap bahan ajar berbasis nilai budaya Using, perolehan hasil validasi dari ahli desain untuk modul belajar siswa mendapatkan persentase skor sebesar $88,89 \%$. Sesuai dengan konversi tingkat validitas dan kualifikasi (tersaji pada tabel 2), hasil validasi dari ahli bahasa ini termasuk dalam kategori "Sangat Valid", sehingga modul belajar siswa ini dapat digunakan tanpa revisi. Adapun hasil validasi untuk modul panduan guru, perolehan hasil uji validasi ahli desain pada modul panduan guru mendapat skor persentase sebesar $94,44 \%$. Sesuai dengan konversi tingkat validitas dan kualifikasi (tersaji pada tabel 3.2), hasil validasi dari ahli desain ini termasuk dalam kategori "Sangat Valid", sehingga modul panduan guru ini dapat digunakan tanpa revisi.

Uji validasi ahli isi diperlukan untuk mengetahui isi yang sudah dikembangkan dalam modul. Adapun hasil validasi ahli isi/materi terhadap bahan ajar berbasis nilai budaya Using ini,hasil perolehan uji validasi ahli isi memperoleh persentase sebesar 97,32\%. Hasil tersebut kemudian dikonversikan menurut tingkat validitas dan kualifikasi (tersaji pada tabel 2), sehingga hasil tersebut mendapat kriteria "Sangat Valid" dan modul belajar siswa ini dapat digunakan tanpa revisi. Ahli isi/materi juga melakukan validasi terhadap modul panduan guru, dimana hasil validasinya adalah sebagai berikut: hasil validasi terhadap modul panduan guru sebesar 97,73\%. Hasil tersebut kemudian dikonversikan menurut tingkat validitas dan kualifikasi (tersaji pada tabel 2) dan memperoleh kriteria "Sangat Valid", sehingga modul panduan guru ini dapat digunakan tanpa revisi.

Uji coba perorangan dilakukan dengan Subjek uji coba sebanyak 3 siswa yang berkemampuan baik, sedang, dan rendah. Uji coba perorangan ini bertujuan untuk mengetahui kemenarikan produk bahan ajar dengan mengidentifikasi dan mengurangi kesalahan-kesalahan nyata dalam produk bahan ajar yang telah disusun. Hasil uji coba perorangan yang telah dilakukan hasil uji coba perorangan mendapatkan rata-rata persentase skor sebesar $78,33 \%$. Sesuai dengan kriteria kemenarikan produk bahan ajar (tersaji pada tabel 3), hasil uji coba perorangan ini termasuk dalam kualifikasi "Cukup Menarik", sehingga bahan ajar berbasis nilai budaya Using ini dapat digunakan dengan revisi kecil.

Uji coba kelompok kecil dilakukan pada hari Kamis, tanggal 19 November 2015 dengan subjek uji coba sebanyak enam orang siswa kelas IV SDN 01 Kemiri Kecamatan Singojuruh Kabupaten Banyuwangi. Ke enam siswa tersebut merupakan dua siswa yang berkemampuan baik, sedang, dan rendah, yang telah dipilih oleh guru kelasnya, yang tentunya berbeda dari siswa yang melakukan uji coba perorangan. Tujuan uji coba kelompok kecil ini juga untuk mengetahui kemenarikan produk bahan ajar. Proses uji coba kelompok kecil dilakukan dengan memberikan arahan tentang hal yang harus dilakukan oleh siswa. Proses uji coba berlangsung selama \pm 30 menit setelah jam istirahat. Hasil uji coba perorangan yang telah dilakukan di perolehan rata-rata persentase skor dari uji coba kelompok kecil adalah sebesar $85,71 \%$. Sesuai dengan konversi tingkat kemenarikan produk bahan ajar (tersaji pada tabel 3), hasil dari uji coba kelompok kecil ini termasuk dalam kategori "Menarik", sehingga modul belajar siswa ini dapat digunakan tanpa revisi.

Uji coba lapangan dalam penelitian ini bertujuan untuk mengetahui keefektifan dan 
keterterapan dari produk bahan ajar berbasis nilai budaya Using yang telah dikembangkan. Subjek dalam uji coba lapangan ini adalah semua siswa kelas IV SDN 01 Kemiri Kecamatan Singojuruh Kabupaten Banyuwangi yang berjumlah 41 siswa dan terdiri dari 18 siswa laki-laki, serta 23 siswa perempuan.

Aktivitas belajar siswa selama proses pembelajaran diamati oleh 1 orang observer. Hasil pengamatan terhadap aktivitas belajar siswa pada uji coba lapangan diperoleh persentase keseluruhan aktivitas siswa adalah sebesar $91,56 \%$. Sesuai dengan kriteria keaktifan siswa (tersaji pada tabel 4), maka aktivitas siswa selama proses pembelajaran menggunakan modul belajar IPS berbasis budaya Using berada pada kategori "Sangat Aktif" dan sudah sesuai dengan "Tingkat Keefektifan" dari modul belajar ini.

Hasil belajar siswa dalam penelitian ini merupakan hasil dari kegiatan siswa dalam mengerjakan soal-soal pada Uji Kompetensi yang terdapat di dalam bahan ajar. Adapun distribusi hasil belajar siswa yatu, skor terendah yang diperoleh siswa adalah 40 dan skor tertingginya adalah 87. Hasil belajar siswa pada rentang skor 72-79 merupakan skor dengan frekuensi terbanyak yaitu 15 (36,58\%), sedangkan rentang skor 48-55 merupakan rentang skor dengan frekuensi paling sedikit yaitu 1 (2,44\%). Hasil belajar siswa kelas IV SDN Kemiri 01 Kecamatan Singojuruh Kabupaten Banyuwangi menunjukkan bahwa siswa yang tuntas adalah 33 siswa $(80,49 \%)$ dan siswa yang belum tuntas adalah 8 siswa $(19,51 \%)$. Sesuai dengan kriteria belajar yang terkait dengan keefektifan bahan ajar yang sudah dibuat, maka persentase siswa yang tuntas lebih dari $75 \%$. Berdasarkan kondisi tersebut, maka bahan ajar yang sudah dikembangkan efektif untuk digunakan dalam proses pembelajaran.

Data tanggapan guru diperlukan untuk mengetahui keterterapan produk bahan ajar yang telah dikembangkan. Data tanggapan guru dikumpulkan melalui angket yang diberikan pada guru yang merupakan pengguna modul panduan guru. Adapun hasil tanggapan guru terhadap modul belajar siswa yaitu hasil tanggapan guru menunjukkan perolehan skor dengan persentase sebesar $93,18 \%$. Sesuai dengan kriteria tingkat keterterapan produk bahan ajar (tersaji pada tabel 5), maka persentase skor dari tanggapan guru mendapatkan kategori "Sangat Baik", sehingga modul belajar untuk siswa ini dapat digunakan tanpa revisi. Adapun untuk hasil tanggapan guru terhadap modul panduan guru yaitu, hasil angket tanggapan guru terhadap modul panduan guru memperoleh persentase skor sebesar $89,29 \%$. Sesuai dengan kriteria tingkat keterterapan produk bahan ajar (tersaji pada tabel 5), maka persentase skor dari tanggapan guru mendapatkan kategori "Sangat Baik", sehingga modul panduan guru ini dapat digunakan tanpa revisi.

Angket tanggapan siswa bertujuan untuk mengetahui tanggapan dari siswa setelah belajar menggunakan modul belajar siswa dan juga untuk mengetahui tingkat keterterapan produk bahan ajar berbasis nilai budaya Using yang telah dikembangkan. Adapun hasil tanggapan siswa diperolehan persentase total skor adalah sebesar $76,80 \%$. Sesuai dengan kriteria tingkat keterterapan produk bahan ajar (tersaji pada tabel 5), maka persentase skor dari tanggapan siswa mendapatkan kategori "Cukup Baik", sehingga modul belajar siswa ini dapat digunakan dengan revisi kecil.

Tujuan analisis data dalam penelitian ini adalah untuk mengetahui tingkat kelayakan produk bahan ajar berbasis nilai budaya Using yang telah dikembangkan berdasarkan kriteria kevalidan, keefektifan, kemenarikan, dan keterterapan produk. Analisis kevalidan produk dilakukan oleh para ahli untuk menguji kevalidan produk bahan ajar berbasis nilai budaya Using yang berupa modul belajar siswa dan modul panduan guru. Kevalidan produk bahan ajar diperlukan sebelum bahan ajar digunakan dalam kegiatan pembelajaran. Hasil Paparan data uji coba validasi dari ahli bahasa, ahli desain, dan ahli isi/materi, direkapitulasi untuk mengetahui tingkat kelayakan produk secara keseluruhan. Adapun hasil rekapitulasi tingkat kelayakan produk dapat dilihat hasil rekapitulasi tingkat kelayakan produk dari ahli bahasa, ahli desain, dan ahli isi/materi mendapatkan skor di atas $75,01 \%$. Hal tersebut berarti sesuai dengan konversi tingkat validitas dan 
kualifikasi (tersaji pada tabel 2) termasuk dalam kategori "Sangat Valid", sehingga bahan ajar berbais nilai budaya Using ini dapat digunakan tanpa revisi.

Tujuan dari pengukuran kemenarikan produk adalah untuk mengetahui motivasi belajar siswa dalam menggunakan bahan ajar berbasis nilai budaya Using, baik dari segi materi maupun desain bahan ajar. Data kemenarikan produk bahan ajar diperoleh dari angket yang diberikan kepada siswa melalui uji perorangan dan uji kelompok kecil dalam menggunakan produk bahan ajar. Rekapitulasi hasil uji coba perorangan dan kelompok kecil di kategori "Cukup Menarik", sehingga bahan ajar berbais nilai budaya Using ini dapat digunakan dengan revisi kecil. Hasil uji coba kelompok kecil termasuk dalam kategori "Menarik", sehingga bahan ajar berbais nilai budaya Using ini dapat digunakan tanpa revisi. Sesuai dengan kondisi tersebut, maka bahan ajar yang sudah dikembangkan memiliki tingkat kemenarikan untuk dapat digunakan dalam proses pembelajaran.

Analisis keefektifan produk bertujuan untuk mengetahui kualitas pembelajaran menggunakan bahan ajar berbasis nilai budaya Using, yang tercermin melalui aktivitas dan hasil belajar siswa. Keefektifan produk bahan ajar dapat diketahui berdasarkan indikator-indikator, yaitu (1) aktivitas siswa selama pembelajaran memperoleh kriteria "Sangat Aktif" dan (2) analisis hasil belajar siswa menunjukkan $80,49 \%$ atau 33 siswa mendapatkan mencapai skor $\geq 70$ dari 100. Berdasakan data-data tentang aktivitas belajar siswa selama proses pembelajaran dan hasil belajar siswa maka bahan ajar IPS berbasis nilai budaya Using ini efektif untuk digunakan dalam proses pembelajaran.

Tujuan dari adanya analisis keterterapan produk adalah untuk mengetahui kesesuaian produk yang dibuat dengan karakteristik pengguna bahan ajar. Keterterapan produk diukur melalui kemudahan guru dan siswa dalam menggunakan bahan ajar. Data keterterapan produk diperoleh melalui uji coba lapangan menggunakan angket tanggapan guru dan siswa. Rekapitulasi dari hasil angket tanggapan guru dan siswa memperoleh persentase skor sebesar
$93,18 \%$ dan angket tanggapan guru terhadap modul panduan guru memperoleh persentase skor sebesar 89,29\%. Sesuai dengan kriteria tingkat keterterapan produk bahan ajar (tersaji pada tabel 5), maka persentase skor dari tanggapan guru mendapatkan kategori "Sangat Baik", sehingga bahan ajar yang sudah dikembagkan dapat digunakan tanpa revisi.

Data keterterapan produk dengan siswa sebagai subjek uji coba, siswa hanya memberikan tanggapan terhadap modul belajar siswa. Perolehan persentase skor angket tanggapan siswa adalah sebesar $76,80 \%$. Sesuai dengan kriteria tingkat keterterapan produk bahan ajar (tersaji pada tabel 5), maka persentase skor dari tanggapan guru mendapatkan kategori "Cukup Baik", sehingga bahan ajar yang sudah dikembagkan dapat digunakan dengan revisi kecil. Berdasarkan hasil analisis keterterapan produk ini, maka dapat disimpulkan bahwa bahan ajar IPS berbasis nilai budaya Using ini telah memenuhi unsur keterterapan, sehingga dapat digunakan dalam proses pembelajaran.

\section{SIMPULAN DAN SARAN}

Berdasarkan paparan data yang sudah diuraikan sebelumnya, maka dapat diambil kesimpulan sebagai berikut: (1) Produk bahan ajar IPS berbasis nilai budaya Using untuk siswa kelas IV SDN 01 Kemiri Kecamatan Singojuruh Kabupaten Banyuwangi dikembangkan berdasarkan SK $1 \mathrm{KD}$ 1.4. Bahan ajar yang dibuat adalah berupa modul belajar siswa dan modul panduan guru dengan judul "Keanekaragaman suku bangsa dan budaya", (2) Kelayakan produk bahan ajar berbasis nilai budaya Using diukur berdasarkan tingkat validitas, tingkat kemenarikan, tingkat keefektifan, dan tingkat keterterapan produk bahan ajar. Tingkat validitas bahan ajar dapat diketahui dari hasil uji validasi ahli, dimana persentase validitas dari ahi bahasa untuk modul belajar siswa adalah $97,92 \%$ dan modul panduan guru adalah $96,43 \%$, persentase dari ahli desain untuk modul belajar siswa adalah $88,89 \%$ dan modul panduan guru adalah $94,44 \%$, dan persentase dari ahli materi/isi untuk modul belajar siswa adalah $97,32 \%$ dan modul panduan guru adalah 97,73\%. 
Tingkat kemenarikan diukur dari uji coba perorangan yang mendapatkan skor $78,33 \%$ dan uji coba kelompok kecil memperoleh persentase skor $85,71 \%$. Tingkat keefektifan bahan ajar diukur dari aktivitas belajar siswa yang mendapatkan persentase skor $91,56 \%$ dan hasil belajar siswa mendapatkan persentase skor $80,49 \%$. Tingkat keterterapan produk bahan ajar diukur berdasarkan angket tanggapan guru yang mendapatkan persentase skor 93,18\% untuk modul belajar siswa dan 89,29\% untuk modul belajar guru, sedangkan angket tanggapan siswa mendapatkan persentase skor $76,80 \%$.

Berdasarkan hasil penelitian yang telah diperoleh, maka dapat disampaikan beberapa saran sebagai berikut: (1) Bagi siswa kelas IV SDN 01 Kemiri Kecamatan Singojuruh Kabupaten Banyuwangi diharapkan untuk semakin rajin membaca dan dapat menulis dengan baik, agar wawasan semakin luas dan saat menuliskan jawaban dapat terbaca dengan baik, sehingga bisa mendapatkan hasil yang maksimal. (2) Bagi guru kelas IV SDN 01 Kemiri Kecamatan Singojuruh Kabupaten Banyuwangi diharapkan dapat memperbaiki tata tulis siswa dan dapat menanamkan nilai-nilai budaya dalam setiap proses pembelajaran.

\section{DAFTAR PUSTAKA}

Akbar, S. \& Sriwiyana, H. 2011. Pengembangan Kurikulum dan Pembelajaran Ilmu Pengetahuan Sosial. Malang: Cipta Media.

Amri, S. \& Ahmadi I. K. (2010). Konstruksi Pengembangan Pembelajaran Pengaruhnya terhadap Mekanisme dan Praktik Kurikulum. Jakarta: Prestasi Pustaka.

Anwar, S. (2014). Pengolahan bahan ajar. Bandung: UPI

Arifin, \& Anwar, S. (2015). Pengembangan Bahan Ajar Ipa Terpadu Tema Udara Melalui Four Steps Teaching Material Development. Jurnal IImu Pendidikan Dan Pengajaran, 2(1), 1-11.

Arsyad, A. (2011). Media Pembelajaran. Jakarta: PT Raja Grafindo Persada
Arthur, E. Teori dan Konsep Pembelajaran. Tersaji dalam http://miftachr.blog.uns.ac.id/2010/01/t eori-dan-konsep pembelajaran.html. (13 Mei 2010)

Departemen Pendidikan Nasional. (2007). Panduan

Farisi, M. I. (2001). Penggunaan Konsep Siswa dalam Pembelajaran Pendidikan IPS. Jurnal Pendidikan, 2(2)(ISSN 1411 - 1942), 78-96.

Hasan S. Hamid. 1996. Pendidikan IImu Sosial. Jakarta: Departemen Pendidikan dan Kebudayaan Direktorat Jenderal Pendidikan Tinggi.

Hasan, Hamid. 2009. Pembelajaran Pendidikan IPS di Sekolah Dasar. dalam

http://www.pembelajaran.wordpress.c om/ Internet diakses tanggal 22 Maret 2014.

Hernowo. (2004). Langkah Mudah Membuat Buku yang menggugah. Bandung: MLC

Hobri. 2010. Metodologi Penelitian Pengembangan (Cetakan 1). Jember: Pena Salsabila.

Hobri. 2010. Metodologi Penelitian Pengembangan (Cetakan 1). Jember: Pena Salsabila. http://wvuecommerce. wvu. edu/ user. (2012). Pengembangan Bahan Ajar Online. Dr. Naswan Suharsono, M.Pd, 1-13.

Lasmawan, Wayan. 2008. "Tujuan Pembelajaran IPS di Sekolah Dasar" Artikel., http://lasmawan.blogspot.com/2008/1 0/tujuan-pembelajaran-ipsdisekolah.html diakses pada 12 Nopember 2012.

Lestari, I. 2012. Pengembangan Bahan Ajar Berbasis Kompetensi. Jakarta: Akademi Permata.

Lestari, I. 2012. Pengembangan Bahan Ajar Berbasis Kompetensi. Jakarta: Akademi Permata.

Majid, A. (2008). Perencanaan Pembelajaran Mengembangkan 
Standar Kompetensi Guru. Bandung: PT Remaja Rodsakarya.

Morgan, S. R. A., Hessler, T, dan Kontad, M. (2007). Teaching Writing for Keeps. Education and Treatment of Childre Vol. 30, No. 3. Diambil pada tanggal 28 April 2014, dari

Muniarti, \& Muslim, M. (2015). Pengembangan Bahan Ajar Mata Kuliah Mekanika Berdasarkan Analisis Kompetensi . Jurnal Pendidikan Fisika Dan Keilmuan (JPFK), 1(2), 67-73.

Muslich, M. (2010). Text Book Writing. Yogyakarta: Ar-ruzz Media.

Pangesti, F. (2012). Pengembangan Bahan Ajar Pendidikan Berpikir (Kritis Dan Kreatif) Berbahasa Indonesia Sma Melalui Pembellajaran Lintas Mata Pelajaran. Universitas Negeri Malang, $1-11$.

Pannen, Paulina Purwanto. (2001). Penulisan Bahan Ajar. Jakarta: PAU PPAI. Ditjen Dikti. Depdiknas.

Pengembangan Bahan Ajar. Jakarta: Direktorat Pembinaan Sekolah Menengah Atas

Piaget, J. \& Inhelder, B. (2010). Psikologi Anak (terj.). Yogyakarta: Pustaka Pelajar.

Prastowo, A. 2011. Panduan Kreatif Membuat Bahan Ajar Inovatif: Menciptakan Metode Pembelajaran yang Menarik dan Menyenangkan. Yogyakarta: DIVA Press.

Prastowo, A. 2011. Panduan Kreatif Membuat Bahan Ajar Inovatif: Menciptakan Metode Pembelajaran yang Menarik dan Menyenangkan. Yogyakarta: DIVA Press.

Siswoyo, A. A. 2012. Pengembangan Perangkat Pembelajaran Matematika Berbasis Realistic Matematc Education (RME). Tesis Tidak diterbitkan. Malang: Universitas Negeri Malang Program Pascasarjana Prodi Dikdas.

Siswoyo, A. A. 2012. Pengembangan Perangkat Pembelajaran Matematika
Berbasis Realistic Matematc Education (RME). Tesis Tidak diterbitkan. Malang: Universitas Negeri Malang Program Pascasarjana Prodi Dikdas.

Somantri, N. (2001). Pembaharuan Pendidikan IPS. Bandung: Remaja Rosda Karya.

Stahl, E. (2008). Personal Epistemologies: Research [Online]. Tersedia di www//roedu.au/cgi/viewcontent.cgi. 2012

Sukadi. 2005. Pendidikan IPS Yang Powerful Dalam Kurikulum Berbasis Kompetensi. Jurnal. Jurnal Pendidikan dan Pengajaran IKIP Negeri Singaraja, No. 4 TH. XXXVIII Oktober 2005

Sukardi, H. M. 2008. Evaluasi Pendidikan Prinsip \& Operasionalnya. Yogyakarta: Bumi Aksara.

Sukardi, H. M. 2008. Evaluasi Pendidikan Prinsip \& Operasionalnya. Yogyakarta: Bumi Aksara.

Sunarya, Yayan. (2005). Pedoman penulisan Buku Ajar Kimia Berbasis Keterampilan Intelektual. Makalah disampaikan pada Pelatihan penulisan Buku Ajar progam Studi Pendidikan Kimia. FKIP Unsri.

Sutarno. 2007. Pendidikan Multikultural. Jakarta: Dirjen Dikti.

Sutarno. 2007. Pendidikan Multikultural. Jakarta: Dirjen Dikti.

Sutarto, A. 2006. "Sekilas Tentang Masyarakat Using". Makalah Disampaikan Pada Acara Pembekalan Jelajah Budaya 2006 Yang Diselenggarakan Oleh Balai Kajian Sejarah Dan Nilai Tradisional Yogyakarta, Tanggal 7-10 Agustus 2006, Dari Www.BpnbJogia.Info/Main/Themes/lmages/Pdf/ Masyarakat Using.Pdf, Diunduh 01 Juni 2015.

Toffler, A. (1980). The Tirth Wave. London: Pan Books, Ltd. 